\title{
Pengaruh Penerapan Pendekatan Pembelajaran ATI (Aptitude Treatment Interaction) terhadap Hasil Belajar Peserta Didik
}

\author{
${ }^{1}$ Muharram \\ ${ }^{1}$ Dosen Jurusan Kimia FMIPA UNM Makassar \\ Email: Muharram_Pasma@yahoo.com
}

\begin{abstract}
Abstrak - Penelitian ini adalah penelitian eksperimen semu yang bertujuan untuk mengetahui pengaruh penerapan pendekatan pembelajaran ATI terhadap hasil belajar peserta didik. Hasil penelitian menunjukkan bahwa nilai rata-rata postes untuk kelas eksperimen adalah 67,79 dengan standar deviasi 11,06, sedangkan untuk kelas kontrol 60,18 dengan standar deviasi 11,07. Pengujian hipotesis dengan menggunakan ANACOVA diperoleh nilai signifikansi $\mathrm{P}=0,0000<\alpha=0,05$, yang menunjukkan bahwa penerapan pendekatan ATI berpengaruh secara signifikan terhadap hasil belajar peserta didik. Hasil belajar kelas eksperimen lebih tinggi daripada kelas kontrol, karena pendekatan ATI dalam proses perkuliahan dapat mengapresiasi kemampuan mahasiswa dari tingkat kemampuan tinggi, sedang dan rendah. Disamping itu, kelompok mahasiswa dengan kemampuan tinggi menjadi tutor terhadap kelompok kemampuan rendah, dan guru bertindak sebagai fasilitator.
\end{abstract}

Kata Kunci: Pendekatan Pembelajaran ATI, Hasil belajar.

Abstract - This study is a quasi experimental research. The aim of this research is to find out the effect of the implementation of ATI approach learning on study result of the students. The results of this research showed that the average of the post test result for the experimental class is 67.79 and the standard deviation is 11.06 , whereas for the control class is 60.18 and the standard deviation is 11.07. Hypothesis was evaluated by ANACOVA and obtained a significant value of $\mathrm{P}=0,0000<\alpha=0,05$ and it is shown that implementation of ATI approach influence significantly to the study result of students. The study result of students of experimental group is higher than control group, because ATI approach in instructional process appreciates student's ability from high, middle and low rank. On the other hand, the students in high ability was placed as tutors for their counterparts for the middle and low ability, and the lecturer still act as facilitator.

Key words: ATI approach learning, study result.

\section{PENDAHULUAN}

Peningkatan kualitas pendidikan merupakan upaya berkelanjutan bagi semua pihak yang terlibat dalam dunia pendidikan. Salah satu wujud upaya peningkatan kualitas pendidikan adalah melalui beragam pembaharuan pembelajaran di berbagai tingkat pendidikan. Pembelajaran merupakan aktivitas utama di semua tingkat pendidikan, sehingga peningkatan kualitasnya tidak dapat dilepaskan dari dampak perkembangan paradigma baru dalam dunia pendidikan, yang mempersyaratkan penyelenggaraan pendidikan yang berpotensi untuk menciptakan keunggulan daya pikir, daya nalar, dan kekuatan moral serta etika akademis bangsa. Terkait dengan hal tersebut, yang menjadi tantangan bangsa kita sekarang ini dan kecenderungan masa depan adalah bagaimana meningkatkan kualitas sumber daya manusia (SDM). Universitas Negeri Makassar (UNM) sebagai salah satu lembaga yang mencetak guru (pendidik) yang sangat berhubungan dengan masalah di atas, karena kualias SDM dapat ditingkatkan dengan menciptakan suatu pendidikan yang unggul. Pendidikan unggul yang dimaksud adalah pendidikan yang dapat mengembangkan potensi dan kapasitas peserta didik secara optimal. Tentunya, hal ini sangat terkait dengan kualitas pembelajaran di kelas tergambar pada aktivitas belajar peserta didik, baik secara fisik maupun mental.

Untuk mengembangkan potensi dan kapasitas peserta secara optimal yang memiliki perbedaan kemampuan, tentunya merupakan suatu tantangan besar bagi seorang pendidik dalam hal ini guru. Para ahli psikologi kognitif seperti Bloom, Piaget dan Gagne (Dahar, R. W, 1988) mengakui adanya keragaman kemampuan individu, yakni ada yang rendah, sedang dan ada pula yang tinggi. Sangat tidak manusiawi jika guru hanya memperhatikan peserta didik yang pintar (kemampuan tinggi) karena mereka yang ada pada golongan sedang dan rendah tidak mampu mengikuti mereka yang berkemampuan tinggi, sedangkan jika guru menuntun peserta yang berkemampuan sedang dan rendah tersebut akan membuat peserta didik pintar menjadi bosan di kelas. Senada dengan hal di atas, Presiden Thomas Jefferson (dalam Suyanto, 2000: 43) mengatakan bahwa there is nothing more equel than equel treatmen of unequal people yang berarti bahwa tidak ada sesuatu yang jauh lebih baik tidak adil dibanding memberikan perlakuan yang sama terhadap orang-orang yang memiliki potensi berbeda.

Upaya perbaikan proses pembelajaran yang dapat mengapresiasi dan mengakomodasi perbedaan kemampuan 
mahasiswa di kelas adalah dengan implementasi pendekatan pembelajaran ATI (Aptitude Treatment Interaction). Pembelajaran ATI merupakan sebuah pendekatan dalam pembelajaran berupaya sedemikian rupa untuk menyesuaikan antara perlakuan dengan kemampuan peserta didik. Penelitian tentang keberhasilan penerapan pendekatan ATI ini telah dilakukan oleh Nurdin S. (2005) dalam pembelajaran IPS SD di propinsi Jawa Barat dan hasilnya adalah peserta didik pada kelas yang diberikan pendekatan pembelajaran ATI memiliki prestasi akademik lebih tinggi secara signifikan dibandingkan kelas yang diberikan pengajaran konvensional. Snow (dalam Nurdin S., 2005) mengemukakan bahwa optimalisasi prestasi akademik (hasil belajar) dapat dicapai melalui penyesuaian antara pembelajaran (treatment) dan perbedaan kemampuan (aptitude).

Mata pelajaran kimia merupakan salah satu mata pelajaran penting di sekolah lanjutan tingkat pertama (SMP) dan sekolah lanjutan tingkat atas (SMA) yang selalu dianggap sulit oleh sebagian besar pesrta didik. Fakta memperlihatkan bahwa hasil belajar peserta didik pada mata pelajaran kimia kurang menggembirakan. Proses pembelajaran yang diterapkan selama ini masih didominasi oleh guru dengan metode ekspositori mengingat materi mata pelajaran kimia sangat sarat dengan rumus-rumus dan membutuhkan penalaran yang tinggi. Minimnya pesrta didik yang memperoleh nilai baik pada mata pelajaran ini merupakan suatu problema tersendiri yang perlu diupayakan perbaikannya.

Faktor utama yang diperkirakan sebagai penyebab munculnya hal tersebut, antara lain; (1) Rendahnya bekal awal peserta didik dalam pemahaman konsep IPA (2) Masalah kesulitan belajar peserta didik karena guru memberikan perlakuan yang sama tanpa mempertimbangkan tingkat kemampuan mereka.

Berdasarkan latar belakang di atas, maka peneliti tertarik untuk menyelidiki pengaruh penerapan pendekatan pembeljaran ATI (Aptitude Treatment Interaction) terhadap hasil belajar pesrta didik.

\section{Pendekatan Pembelajaran Berbasis Aptitude Treatment Interaction (ATI)}

Aptitude Tretment Interaction (ATI) Approach merupakan sebuah pendekatan dalam pembelajaran yang berupaya sedemikian rupa untuk menyesuaikan pembelajaran dengan karakteristik kemampuan peserta didik. Secara substantif dan teoritik, pembelajaran ATI dapat diartikan sebagai sebuah konsep atau model yang memiliki sejumlah strategi pembelajaran (treatment) yang efektif digunakan untuk menangani individu tertentu sesuai dengan kemampuannya masing-masing. Ini berarti bahwa ATI didasari oleh asumsi bahwa optimalisasi prestasi akademik/hasil belajar dapat dicapai melalui penyesuaian antara perlakuan (treatment) dengan perbedaan kemampuan (aptitude) peserta didik (Nurdin, S. 2005: 37).
Cronbach mendefinisikan pendekatan ATI sebagai sebuah pendekatan yang berusaha mencari dan menemukan perlakuan-perlakuan (treatment) yang cocok dengan perbedaan kemampuan (aptitude) peserta didik, yaitu treatment yang secara optimal efektif diterapkan untuk peserta didik yang berbeda tingkat kemampuannya. Secara stasistik dan metodologi, pendekatan ATI dimaknai sebagai suatu interaksi statistik yang bersifat multiplikatif (gabungan) dari sekurang-kurangnya satu variabel manusia (independent) dan satu variabel treatment yang bersifat independent.

Berdasarkan pengertian-pengertian yang dikemukakan di atas, dapat diperoleh beberapa makna esensial dari ATI Approach, sebagai berikut: Pertama, pendekatan ATI merupakan suatu konsep atau model yang berisikan sejumlah strategi pembelajaran (treatment) yang efektif digunakan untuk peserta didik tertentu sesuai dengan perbedaan kemampuannya. Kedua, sebagai sebuah kerangka teoritik, pendekatan ATI berasumsi bahwa optimalisasi prestasi akademik/hasil belajar akan tercipta bilamana treatment dalam pembelajaran disesuaikan sedemikian rupa dengan perbedaan kemampuan (aptitude) peserta didik. Ketiga, terdapat hubungan timbal balik antara prestasi akademik/hasil belajar yang dicapai peserta didik dengan pengaturan kondisi pembelajaran di kelas. Dengan kata lain, prestasi akademik/hasil belajar yang diperoleh pesta didik (achievement) tergantung pada kondisi pembelajaran yang dikembangkan guru di kelas.

Dari rumusan pengertian dan makna esensial yang telah dikemukakan di atas, tampak bahwa secara hakikat pendekatan ATI bertujuan untuk menciptakan dan mengembangkan suatu model pembelajaran yang betul-betul peduli dan memperhatikan keterkaitan antara kemampuan (aptitude) seseorang dengan metode pembelajaran (treatment).

Untuk mencapai tujuan seperti digambarkan di atas, pendekatan ATI berupaya menemukan dan memilih sejumlah pendekatan, metode/cara, strategi, dan kiat yang akan dijadikan sebagai treatmen yang tepat, yaitu treatment yang sesuai dengan tingkat kemampuan peserta didik. Selanjutnya, melalui suatu interaksi yang bersifat multiplikatif dikembangkan perlakuan-perlakuan tersebut dalam pembelajaran, sehingga akhirnya dapat diciptakan optimalisasi prestasi akademik/hasil belajar. Keberhasilan model pendekatan ATI mencapai tujuan dapat dilihat dari sejauh mana terdapat kesesuaian antara treatment yang telah diimplementasikan dalam pembelajaran dengan kemampuan peserta didik.

Agar tingkat keberhasilan (efektifitas) pengembangan model pembelajaran ATI dapat tercapai dengan baik, maka dalam implementasinya perlu diperhatikan dan dihayati beberapa prinsip yang dikemukakan oleh Snow (1989) berikut ini. Pertama, interaksi antara aptitude dan treatment pembelajaran berlangsung di dalam pola yang kompleks, dan senantiasa dipengaruhi oleh variabel-variabel tugas/jabatan dan situasi. Oleh karena itu, dalam mengimplementasikan 
model pembelajaran ATI perlu diperhatikan dan diminimalkan bias yang diperkirakan mungkin berasal dari variabel-variabel tersebut. Kedua, lingkungan pembelajaran yang sangat terstruktur cocok bagi peserta didik yang memiliki kemampuan rendah, sedangkan lingkungan pembelajaran yang kurang terstuktur (fleksibel) lebih pas untuk peserta didik yang pandai. Ketiga, bagi peserta didik yang memiliki rasa percaya diri kurang atau sulit dalam menyesuaikan diri (pencemas atau minder), cenderung belajarnya akan lebih baik bila berada dalam lingkungan belajar yang sangat terstruktur. Sebaliknya, bagi peserta didik yang tidak pencemas atau memiliki rasa percaya diri tinggi (independent), belajarnya akan lebih baik dalam situasi pembelajaran yang agak longgar (fleksibel).

Teori-teori pembelajaran (meliputi kaidah-kaidah psikologis dan belajar) yang relevan dijadikan landasan pengembangan model pembelajaran ATI (Nurdin, S. 2005: 73-76) diantaranya:

1. Teori pembelajaran behavioristik; yang beranggapan bahwa "pengembangan anak ditentukan oleh faktor-faktor yang berasal dari lingkungan, atau belajar dapat dibentuk oleh lingkungan"(Nana Syaodih S, 1997 : 54). Bertolak dari prinsip-prinsip, kaidah-kaidah konsep, serta anggapan yang dianut oleh teori pembelajaran behavioristik, maka ditetapkan dan dipilihlah beberapa sistem dan model pembelajaran yang relevan untuk dikembangkan sebagai perlakuan (treatment) dalam implementasi model pendekatan ATI, diantaranya melalui pengajaran individual (Self-Interaction); yang diwujudkan dalam bentuk belajar mandiri/sendiri (Self-learning) dengan menggunakan modul-plus. Belajar mandiri (Selflearning) dipilih menjadi treatment untuk siswa berkemampuan tinggi, karena dipandang sesuai dengan prinsip-prinsip pengembangan model pembelajaran ATI. Peserta didik yang berkemampuan tinggi cenderung belajarnya akan lebih berhasil dalam suasana yang tidak terlalu terstruktur (fleksibel) dan yang memiliki tingkat kebebasan yang lebih tinggi (freedom). Kondisi seperti ini analog dengan beberapa karakteristik pengajaran yang menggunakan sistem modul, yakni adanya kebebasan dan bersifat lentur (fleksibel).

2. Teori belajar kognitif, Jerome Bruner, yang memayungi model pembelajaran inquiry training yang berada pada rumpun The Processing Information Model (diadaptasi seperlunya), yang juga menjadi pilihan tersendiri bagi model pendekatan ATI untuk dikembangkan menjadi perlakuan-perlakuan bagi peserta didik yang memiliki kemampuan tinggi. Sebab prinsip-prinsip belajar yang ada dalam model inquiry training, pada dasarnya mendorong peserta didik aktif belajar menemukan (discovery learning). Dalam konteks studi ini, yaitu melakukan pengumpulan informasi dan eksplorasi hal-hal yang berhubungan dengan materi pelajaran, baik melalui buku maupun melalui buku-buku teks pelajaran yang relevan. Selanjutnya, peserta didik menyimpulkan dan memformulasikan penjelasan-penjelasan tentang apa yang sudah dibaca, dipelajari dan dibahas melalui self-learning, sehingga dianggap cukup relevan untuk diterapkan pada peserta didik yang pandai (cerdas).

3. Teori belajar bermakna "David Ausabel" (Sub sumption theory of meaningfull verbal learning), yang menekankan pentingnya kebermaknaan dalam belajar. Menurut teori ini, belajar bermakna (meaningfull learning) dapat diperoleh melalui reorganisasi pengerahan yang sudah ada dan menggabungkannya dengan pengetahuan baru. Kunci untuk memperoleh kebermaknaan dalam belajar adalah melalui keterhubungan secara kuat (solid) antara pengetahuan baru dengan keberadaan ide-ide (pengetahuan yang telah dimiliki/ada) dalam struktur kognitif siswa.

4. Prinsip, kaidah, dan pembelajaran yang bersumber dari pendekatan psikologis humanistik juga diadaptasikan oleh model pendekatan ATI, terutama seperti yang dikemukakan oleh Rogers tentang perlunya guru memfasilitasi tumbuhnya kemampuan belajar peserta didik yang lebih baik dan yang ditekankan ole Maslow mengenai perlunya memberi motivasi kepada peserta didik dalam mengikuti pembelajaran. Kedua konsep tersebut pas digunakan untuk peserta didik yang berkemampuan rendah atau lambat dalam belajar, karena peserta didik dari kelompok ini amat memerlukan perhatian, kesabaran, dorongan/motivasi dari guru selama dalam mengikuti pembelajaran. Dengan memfasilitasi tumbuhnya kemampuan belajar dan memberi dorongan atau motivasi, terutama kepada peserta didik kelompok sedang dan rendah, diharapkan muncul pada masingmasing peserta didik "rasa senang belajar" atau dengan istilah yang sangat popular dewasa ini adalah terwujudnya quantum learning, yaitu suatu kondisi/suasana belajar yang menyenangkan bagi peserta didik.

Teori-teori intelegensi dan konsep-konsep yang dijadikan landasan bagi pengembangan model pendekatan ATI dalam studi ini antara lain (Nurdin, S. 2005: 77-79):

1. Teori analisis Faktor Sperman, yang menyatakan bahwa intelegensi atau kemampuan manusia ditentukan oleh dua faktor, yaitu: 1) faktor umum (general factor), dan 2) faktor-faktor khusus tertentu (special factor). Teori ini berpendapat bahwa faktor umum (g) adalah pembawa yang tergantung kepada dasar yaitu pembawaan yang dibawa dari lahir (heredity) dan faktor khusus (s), yaitu faktor yang dapat dipengaruhi oleh pengalaman (lingkungan, pendidikan).

2. Teori Thomson, yang tidak mengakui pendapat Spearman tentang adanya faktor "g", tetapi membenarkan bahwa pada diri manusia terdapat bermacam-macam faktor khusus (faktor s). Menurut Thomson (dalam Sumadi Suryabrata, 1987: 132) bahwa faktor-faktor "s" ini tidak tergantung pada keturunan atau dasar, melainkan tergantung pada kecerdasan. Anak-anak dari golongan 
tinggi lebih cerdas daripada anak-anak dari golongan rendah, bukan karena mereka lebih banyak mempunyai kesempatan untuk belajar". Dari pernyataan Thomson ini pendidikan dan pengajaran kemampuan (intelligence) yang dimiliki oleh manusia itu dapat dikembangkan.

3. Teori Cyrill Burt dan Thurstone; disamping memiliki prinsip dan pendirian yang sama dengan teori Spearman yaitu sama-sama mengakui bahwa pada diri manusia terdapat faktor "g" (faktor yang dibawa sejak lahir) dan faktor "s". Teori ini juga menambahkan bahwa faktor "s" yang dipunyai manusia itu banyak jumlahnya, yaitu sebanyak tingkah laku khusus yang dilakukan oleh manusia dalam kehidupannya.

4. Teori Intellegence Leon Kamin, yang menyatakan bahwa kemampuan (intelligence) manusia bakanlah semata-mata ditentukan oleh faktor genetik atau bawaan dari lahir (heredity), tapi lebih banyak ditentukan oleh faktor-faktor lingkungan. Seperti terungkap dari perbedaan pandangannya dengan Eysency dalam pendahuluan buku "The intelligence Controversy" yang berarti bahwa melalui penjelasan yang dikembangkan lewat sejumlah strategi, metode, pendekatan ataupun perlakuan-perlakuan dapat ditingkatkan kemampuan (intelligence) siswa. Dengan kata lain, teori Leon Kamin menganggap bahwa inteligensi itu bersifat dinamis, dan dapat meningkat serta berkembang melalui usaha pendidikan (lingkungan).

5. Teori Multiple Intelligence merupakan salah satu teori yang bersesuaian dengan pemgembangan model pendekatan ATI. Oleh karena itu, model pendekatan ATI menyatakan konsistensinya pada multiple intelligence. Sebagaimana ditegaskan Cronbach dan Snow bahwa "model pendekatan ATI konsisten dengan teori-teori intelligence". Selain itu, teori multiple intelligence yang dipelopori oleh Gardner, Stenberg dan Guilford ternyata banyak memiliki kesesuaian dengan teori-teori belajar modern yang mempunyai pandangan bahwa inteligensi itu bersifat multi dimensi dan dinamis. Pandangan teori multi intelligence tentang sifat dinamis inilah yang dijadikan landasan berpijak oleh model pendektan ATI untuk mengembangkan perlakuan-perlakuan yang relevan kepada masing-masing karakteristik kemampuan siwa dalam pembelajaran, sehingga pada gilirannya nanti dapat diciptakan optimalisasi prestasi akademik/hasil belajar.

Dengan demikian, dapat dimengerti bahwa pengembangan model pendekatan ATI tidak hanya berlandaskan kepada satu teori tertentu, tetapi menggunakan prinsip-prinsip dan konsep pembelajaran yang dianggap relevan dari beberapa teori lain. Hal ini disebabkan oleh karakteristik dan spesifikasi model yang memang menghendaki adanya variasi dalam pemberian perlakuan-perlakuan kepada masing-masing kelompok kemampuan siswa (tinggi, sedang, dan rendah).

\section{Hasil Belajar}

Menurut Udin ( 2001: 26 ), hasil belajar berupa perubahan perilaku atau tingkah laku. Seseorang yang belajar akan berubah perilakunya, baik yang berupa pengetahuan, keterampilan motorik, atau penguasaan nilai-nilai (sikap). Howard Kingsley berpendapat dalam penilaian hasil belajar dan proses pembelajaran membagi tiga macam hasil belajar, yakni keterampilan dan kebiasaan, pengertian serta sikap dan cita-cita, sedangkan Gagne membagi lima kategori hasil belajar, yakni informasi verbal, keterampilan intelektual, strategi kognitif, sikap dan keterampilan motorik. Dalam sistem pendidikan nasional rumusan tujuan pendidikan, baik tujuan kurikuler maupun tujuan instruksional, menggunakan hasil belajar dari Benyamin Bloom yang secara garis besar membagi tiga ranah, yakni ranah kognitif, ranah afektif, dan ranah psikomotorik. Ranah kognitif, menaruh perhatian pada pengembangan keterampilan intelektual, Ranah psikomotorik berkaitan dengan kegiatan-kegiatan manipulatif atau keterampilan motorik, dan ranah afektif berkaitan dengan pengembangan perasaan, sikap, nilai, dan emosi. Dapat diasumsikan bahwa untuk menghasilkan ketiga ranah hasil belajar tersebut ditentukan atau dipengaruhi oleh faktor internal seperti pengetahuan prasyarat atau kemampuan awal dari masing-masing kategori hasil belajar yang telah dimiliki oleh peserta didik yang berkaitan dengan keterampilan yang sedang dipelajari.

Hasil belajar yang dicapai peserta didik ataupun mahasiswa dipengaruhi oleh dua faktor utama, yakni faktor dari dalam diri peserta didik dan faktor dari luar diri peserta didik atau faktor lingkungan. Faktor dari dalam diri peserta didik terutama menyangkut kemampuan yang dimilikinya. Faktor kemampuan peserta didik besar sekali pengaruhnya terhadap hasil belajar yang dicapai. Clark (dalam Angkono, 2007) mengungkapkan bahwa hasil belajar peserta didik di sekolah $70 \%$ dipengaruhi oleh kemampuan peserta didik dan $30 \%$ dipengaruhi oleh lingkungan. Berkaitan dengan faktor dari dalam diri peserta didik, selain faktor kemampuan, ada juga faktor lain, yaitu motivasi, minat, perhatian, sikap, kebiasaan belajar, ketekunan, kondisi sosial ekonomi, kondisi fisik dan psikis. Salah satu faktor lingkungan yang paling dominan mempengaruhi hasil belajar adalah kualitas pengajaran. Kualitas pengajaran adalah tinggi rendahnya atau efektif tidaknya proses pembelajaran dalam memcapai tujuan instruksional.

Berdasarkan uraian di atas, dapat disimpulkan bahwa hasil belajar adalah hasil yang diperoleh peserta didik setelah melibatkan diri secara aktif baik faktor fisik maupun mental dalam menyelesaikan masalah-masalah yang berhubungan dengan kimia. Hasil belajar dalam pembelajaran, khususnya mata pelajaran kimia dapat ditingkatkan dengan berbagai cara, salah satu diantaranya adalah dengan menerapkan pendekatan ATI.

\section{METODE PENELITIAN}

Penelitian ini adalah penelitian eksperimen semu yang terdiri dari dua variabel, yaitu variabel terikat dan variabel 
bebas. Hasil belajar peserta didik pada mata pelajaran Kimia merpakan variabel terikat, sedangkan penggunaan pendekatan pembelajaran ATI sebagai variabel bebas.

Penelitian ini melibatkan dua kelas yaitu kelas eksperimen dan kelas kontrol. Adapun desain penelitian yang digunakan dalam penelitian ini adalah "Randomized Pretest-Post-test control Group Desain" dengan pola:

\begin{tabular}{|c|c|c|c|c|}
\hline \multirow{2}{*}{$\mathrm{R}$} & $\mathrm{E}$ & $\mathrm{O} 1$ & $\mathrm{X} 1$ & $\mathrm{O} 2$ \\
\cline { 2 - 5 } & $\mathrm{K}$ & $\mathrm{O} 3$ & $\mathrm{X} 2$ & $\mathrm{O} 4$ \\
\hline
\end{tabular}

$$
\text { Ket. } \begin{aligned}
\mathrm{R} & =\text { Random } \\
\mathrm{E} & =\text { Kelas eksperimen } \\
\mathrm{X}_{1} & =\text { Pembelajaran dengan pendekatan ATI } \\
\mathrm{X}_{2} & =\text { Pembelajaran Konvensional } \\
\mathrm{O}_{1} & =\text { Pretest kelas ekperimen } \\
\mathrm{O}_{2} & =\text { Posttest kelas ekperimen } \\
\mathrm{K} & =\text { Kelas kontrol } \\
\mathrm{O}_{3} & =\text { pretest kelas kontrol } \\
\mathrm{O}_{4} & =\text { posttest kelas kontrol }
\end{aligned}
$$

\section{Definisi Operasional}

1. Pembelajaran dengan pendekatan ATI adalah pembelajaran yang memperhatikan keragaman individu peserta didik. Perlakuan yang diberikan kepada peserta didik disesuaikan dengan tingkat kemampuannya. Pada penerapannya, peserta didik dibagi dalam tiga kelompok, yakni kelompok dengan kemampuan tinggi, sedang, dan rendah. Pengelompokan tersebut berdasarkan pada hasil tes awal. peserta didik yang memiliki hasil ujian di bawah nilai 60 diasumsikan memiliki kemampuan yang rendah, nilai 61-74 diasumsikan memiliki kemampuan yang sedang, dan di atas nilai 75 diasumsikan memiliki kemampuan yang tinggi.

2. Hasil belajar yang dimaksud adalah nilai yang diperoleh peserta didik melalui tes hasil belajar sebelum pembelajaran (pretest) dan tes hasil belajar setelah pembelajaran (Posttes).

\section{Pelaksanaan Penelitian}

Penelitian dilakukan selama 16 minggu, dengan jumlah pertemuan 32 kali $(a=2 \times 45$ menit). Kegiatan perkuliahan untuk kelas eksperimen dan kelas kontrol dilakukan oleh guru yang sama.

Tabel 1. Langkah-langkah pembelajaran kelompok eksperimen dan kontrol:

\begin{tabular}{llr}
\hline \multicolumn{1}{c}{ Kelas control } & \multicolumn{2}{c}{ Kelas eksperimen } \\
\hline Kegiatan Awal; & Kegiatan Awal; & \\
Membuka & - Membuka & pembelajaran \\
pembelajaran dengan & \multicolumn{1}{c}{ dengan } & memberikan \\
memberikan apersepsi & apersepsi serta menjelaskan \\
serta menyampaikan & tujuan pembelajaran yang \\
tujuan pembelajaran & akan diberikan. \\
yang akan diberikan. & - Membagi mahasiwa \\
Kegiatan Inti; & berdasarkan nilai pretesnya. \\
- Menjelaskan & Kegiatan Inti; \\
\hline
\end{tabular}

pokok-pokok materi pembelajaran.

- Memberikan soalsoal latihan di kelas yang memuat konsep pembelajaran dengan soal yang sama untuk semua peserta didik.

- Diskusi kelas dengan memberikan kesempatan kepada peserta didik untuk bertanya mengenai hal-hal yang belum dipahami

Penutup;

- Mengarahkan peserta didik untuk menarik kesimpulan

- memberikan tugas rumah sama untuk semua peserta didik.
- Menjelaskan pokok-pokok materi pembelajaran.

- Memberikan soal-soal latihan di kelas yang memuat konsep pembelajaran dengan klasifikasi soal rumit untuk kelompok tinggi, soal sedang untuk tingkat kemampuan sedang dan soal rendah untuk kemampuan rendah.

- Diskusi kelas dengan memberikan kesempatan kepada wakil setiap tingkat kemampuan untuk memaparkan hasil pekerjaannya (mengerjakan di white board).

- Untuk soal-soal/masalah yang kompleks bagi peserta didik dari kelompok berkemampuan tinggi menjadi tutor bagi kelompok berkemampuan rendah diluar jam perkulihan atas fasilitasi guru (ini merupakan spesial treatmen untuk kelompok rendah).

Penutup;

- Mengarahkan peserta didik untuk menarik kesimpulan perkuliahan

- Memberikan Tugas rumah dengan soal yang berbeda untuk tiga kelompok kemampuan

\section{HASIL PENELITIAN}

Gambaran tentang karakteristik distribusi nilai peserta didik kelas eksperimen dan kelas kontrol dapat dilihat pada tabel 2 .

Tabel 2. Hasil analisis statistika deskriptif untuk kelas eksperimen dan kelas kontrol

\begin{tabular}{ccccc}
\hline \multirow{2}{*}{ Statistik } & \multicolumn{4}{c}{ Nilai Statistika } \\
\cline { 2 - 5 } & \multicolumn{2}{c}{ Nilai pretest } & \multicolumn{2}{c}{ Nilai postest } \\
\cline { 2 - 5 } Eksperimen & Kontrol & Eksperimen & Kontrol \\
\hline $\begin{array}{c}\text { Jumlah } \\
\text { sampel } \\
\text { Nilai }\end{array}$ & 34 & 33 & 34 & 33 \\
ideal & 100 & 100 & 100 & 100 \\
Nilai & 32 & 25 & 42 & 40
\end{tabular}


terendah

\begin{tabular}{ccccc}
$\begin{array}{c}\text { Nilai } \\
\text { tertinggi } \\
\text { Nilai }\end{array}$ & 80 & 80 & 87 & 80 \\
$\begin{array}{c}\text { rata-rata } \\
(\mathrm{X})\end{array}$ & 55,73 & 54,00 & 67,79 & 60,18 \\
$\begin{array}{c}\text { Standar } \\
\text { deviasi } \\
(\mathrm{SD})\end{array}$ & 14,53 & 14,05 & 11,06 & 11,07 \\
\hline
\end{tabular}

Tabel 2 menunjukkan bahwa peserta didik pada kelas eksperimen memiliki rata-rata pretes sebesar 55,73 dengan standar deviasi 14,53, sedangkan untuk kelas kontrol ratarata pretes 54,00 dengan standar deviasi 14,05. Tampak bahwa keduanya memiliki rata-rata yang hampir sama. Untuk nilai posttes (ujian Kimia Fisik II) rata-rata untuk kelas eksperimen adalah 67,79 dengan standar deviasi 11,06 dan untuk kelas kontrol 60,18 dengan standar deviasi 11,07.

\section{A. Pengujian Persyaratan Analisis}

Syarat yang harus dipenuhi sebelum melakukan pengujian hipotesis adalah melakukan pengujian normalitas dan homogenitas. Perhitungan dilakukan dengan menggunakan bantuan komputer program Statistical Package for Social Sciences (SPSS) 10 for wndows

1. Uji Normalitas

Uji normalitas dilakukan dengan menggunakan uji OneSampel Kolmogorov-Smirnorv test. Uji normalitas dilakukan untuk data pretest dan posttest masing-masing kelas. Hasil yang diperoleh untuk data pretest masing masing-masing kelas eksperimen dan kelas kontrol berdistribusi normal, dengan nilai signifikansi $\mathrm{p}=0,778>\alpha=0,05$ dan $\mathrm{p}=0,504$ $>\alpha=0,05$. Begitu pula hasil yang diperoleh untuk data posttest masing-masing kelas eksperimen dan kelas kontrol berdistribusi normal, yaitu nilai signifikansi $\mathrm{p}=0,477>\alpha=$ 0,05 dan $\mathrm{p}=0,663>\alpha=0,05$. Kriteria pengujian data berdistribusi normal jika nilai signifikansi yang diperoleh lebih besar dari $\alpha=0,05$. Untuk data selengkapnya, dapat dilihat pada lampiran analisis data.

2. Uji Homogenitas

Pengujian dilakukan dengan data pretest dan posttest masing-masing kelas dilakukan dengan menggunakan Uji Univariate Analysis Of Varians. Berdasarkan hasil pengujian homogenitas varians untuk data pretest dan posttest diperoleh nilai signifikansi $\mathrm{P}=0,268>\alpha=0,05$ dan $\mathrm{P}=0,842>\alpha=$ 0,05 . Kriteria pengujian varian sampel dinyatakan homogen. Data selengkapnya, dapat dilihat pada lampiran analisis data

\section{B. Pengujian Hipotesis}

Berdasarkan pengujian persyaratan analisis, diperoleh nilai pretest dan postest masing-masing kelas berdistribusi normal dan varians data pretest dan posttest sampel dinyatakan homogen. Selanjutnya untuk pengujian hipotesis digunakan Analysis of Covariance (ANACOVA). Hasil analisis diperoleh nilai signifikansi $\mathrm{P}=0,000<\alpha=0,05$.
Kriteria pengujian, $\mathrm{H}_{0}$ diterima jika nilai signifikansi lebih besar dari $\alpha=0,05$, dan $\mathrm{H}_{0}$ ditolak jika signifikansi lebih kecil dari $\alpha=0,05$. Berdasarkan hasil analisis tersebut, maka hipotesis $\mathrm{H}_{0}$ ditolak dan $\mathrm{H}_{1}$ diterima. Hal ini berarti bahwa penerapan pendekatan ATI berpengaruh signifikan terhadap hasil belajar peserta didik.

\section{PEMBAHASAN}

Berdasarkan hasil analisis statistika dengan menggunakan SPSS 10 for windows, mengenai data homogenitas varians untuk pretes dalam hal ini hasil ujian kimia untuk kelas kontrol dan eksperimen diperoleh nilai signifikansi $P=0,436>\alpha=0,05$. yang menunjukkan bahwa kedua kelas memiliki kemampuan yang sama atau homogen sebelum mendapat perlakuan. Setelah diberikan perlakuan, diperoleh nilai tertinggi untuk kelas eksperimen adalah 87, nilai rata-rata $(\mathrm{X})$ pada postest adalah 67,79, dan standar deviasi adalah 11,067, sedangkan pada kelas kontrol memperoleh nilai tertinggi adalah 80 , nilai rata-rata $(X)$ pada postest adalah 60,00 dan standar deviasi adalah 11,075. Hasil analisis tersebut menunjukkan bahwa nilai rata-rata $(\mathrm{X})$ posttest pada kelas eksperimen lebih besar dibanding dengan nilai rata-rata $(\mathrm{X})$ posttest pada kelas kontrol dan standar deviasi posttest pada kelas eksperimen hampir sama dengan kelas kontrol. Hal ini menunjukkan bahwa hasil pada kelas ekperimen yang menggunakan pendekatan ATI lebih baik (tinggi) dibanding dengan kelas kontrol yang diajar dengan konvensional. Salah satu faktor yang menyebabkan adalah adanya perbedaan cara mengajar yang diterapkan pada kedua kelas tersebut. Penggunaan pendekatan ATI dalam proses pembelajaran dapat mengapresiasi peserta didik berdasarkan tingkat kemampuannya masing-masing. Disamping itu, kelompok peserta didik dengan kemampuan tinggi yang terdiri dari lima peserta didik, bertindak sebagai tutor bagi kelompok peserta didik untuk kelompok dengan kemampuan rendah yang terdiri dari 20 peserta didik dengan perbandingan $1: 4$. Hal ini juga dapat meningkatkan motivasi belajar peserta didik kemampuan rendah, karena dalam proses belajar mereka di luar kelas dapat lebih komunikatif dan lebih leluasa, mengingat mereka berada pada level yang sama.

Menurut penulis setelah melakukan penelitian ini, terdapat beberapa kendala dan kelemahan dalam menerapkan model pembelajan ATI ini, diantaranya adalah membutuhkan waktu, tenaga, dan biaya yang cukup banyak serta fasilitas yang lengkap dan memadai terkhusus fasilitas belajar bagi peserta didik kelompok kemampuan tinggi. Ruangan yang dibutuhkan harus kondusif yang dilengkapi dengan bukubuku referensi dan alat belajar penunjang lainnya yang belum semuanya tersedia.

\section{PENUTUP}

Berdasarkan hasil analisis statistika inferensial diperoleh bahwa penerapan Pendekatan pembelajaran ATI (Aptitude Treatmen Interaction) berpengaruh secara 
segnifikan terhadap hasil belajar peserta didik pada mata pelajaran kimia.

Berdasarkan hasil penelitian yang telah dilakukan, maka penulis menyarankan kepada guru Kimia untuk mempertimbangkan menggunakan penekatan pembelajaran ATI dalam proses pembelajaran untuk mengapresiasi tingkat kemampuan peserta didik yang berbeda-beda. Kepada penentu kebijakan, kiranya mempertimbangkan fasilitas (sarana dan prasarana) yang dapat menunjang proses perkuliahan peserta didik dengan tingkat kemampuan tinggi, sedang dan rendah.

\section{PUSTAKA}

[1] Abu A. dan Joko T.P. 1997. Strategi Belajar Mengajar. Jakarta: Pustaka Setia.

[2] Dahar. 1989. Teori-teori belajar. Jakarta: Erlangga.

[3] Dimyati. 1994. Belajar dan Pembelajaran. Jakarta: Direktorat jenderal Perguruan Tinggi, Departemen Pendidikan dan Kebudayaan.

[4] Nana Sudjana. 2004. Penilaian Hasil Proses Belajar Mengajar. Bandung: PT Remaja Rosdakarya.

[5] Nurdin S. 2005. Penerapan Model Pendekatan Aptitude Treatment Interaction (ATI) dalam Pembelajaran IPS di $S D$. Tersedia pada http:// digilib.upi.edu/pasca/available. Diakses tanggal 10 Juni 2007.

[6] Nurdin S. 2005. Model Pembelajaran yang Memperhatikan Keragaman Individu Siswa dalam Kurikulum Berbasis Kompetensi. Bandung : Quantum Teaching.

[7] Sardiman. 2000. Interaksi dan Motivasi Belajar Mengajar. Yogyakarta: Rajawali Press

[8] Slameto. 1991. Proses Belajar Mengajar dalam Sistem SKS. Jakarta: Bumi Aksara.

[9] Suyanto dan Hisyam D. 2000. Refleksi dan Reformasi Penidikan di Indonesia Memasuki Milenium III. Yogyakarta : Adicita Karya Nusa
[10] Udin.S. Winata. 2001. Strategi Belajar Mengajar. Jakarta: Pusat Penerbitan Universitas Terbuka. 